\title{
Geoelectrical Survey for Groundwater Potential in Song and Environs NE, Nigeria
}

\author{
A. Yakubu and A. Nur
}

Department of Geology, Modibbo Adama University of Technology, Yola, Nigeria

\begin{abstract}
Seventeen Vertical Electrical soundings (VES) using the Schlumberger configuration with current electrode spacing of $A B / 2=80 \mathrm{~m}$ were carried out in Song and environs of Adamawa State of Nigeria to study the groundwater potential. Sixteen VES showed a three-layer earth model; while the remaining one has four-layer earth model. The average thickness of the first layer is $2 \mathrm{~m}$ with a mean resistivity of $75.14 \Omega \mathrm{m}$; representing the top soil and clay material. The second layer has an average thickness of $12.09 \mathrm{~m}$ with a mean resistivity of $50.0 \Omega \mathrm{m}$. This layer is unconsolidated and highly weathered/fractured basement. The average resistivity value of the third layer is $5150 \Omega \mathrm{m}$ and represents the fresh basement. Water samples were collected from Seven Boreholes $(\mathrm{BH})$ and four Hand-Dug wells (HDW). The overall assessment of the sampled water in the area indicates an average $\mathrm{pH}$ value of 5.8 , mean temperature of $28.96^{\circ} \mathrm{C}$, an average turbidity value of $0.453 \mathrm{NTU}$, and with a mean conductivity value of $159.39 \mu \mathrm{s} / \mathrm{cm}$. The water is mostly acidic with a moderate temperature, and turbidity. Total hardness has an average value of $98.78 \mathrm{mg} / \mathrm{l}$ indicating a moderately soft water quality. All the Hand-Dug wells in the study area have high concentration of Nitrate and total Coliform count of $50.93 \mathrm{mg} / \mathrm{l}$ to $67.17 \mathrm{mg} / \mathrm{l}$ and $12 \mathrm{cfu} / \mathrm{ml}$ to $27 \mathrm{cfu} / \mathrm{ml}$ respectively. The high value can be attributed to anthropogenic activities such as chemical fertilizer application and indiscriminate dumping of house hold solid waste in the area as well as animals and human faeces. The high concentration of total coliform count was also observed in BH4 because of the shallow depth. Apart from the HDW and $\mathrm{BH} 4$ that are of shallow depth, the groundwater is generally good for human as well as industrial and agricultural uses.
\end{abstract}

Keywords: Geo-electrical Survey, Song and environs, groundwater potentials and water quality.

\section{INTRODUCTION}

The study area is located between latitude $9^{\circ} 48^{\prime} \mathrm{N}$ and $9^{\circ} 52^{\prime} \mathrm{N}$ and longitude $12^{\circ} 35^{\prime} \mathrm{E}$ and $12^{\circ} 39^{\prime} \mathrm{E}$ in Song Local Government Area of Adamawa state, within $1: 50,000$ topographical sheets 176 of Zummo NW, Nigeria (Figure 1). The area is accessible by Trunk ' $A$ ' Yola - Gombi Federal road and is about $74 \mathrm{~km}$ north of Yola and by several foot paths and Cattle routes traversing the area. The study area has a total land area of $53.58 \mathrm{~km}^{2}$.

The area is highly rugged and generally undulating; the lowest elevation ranges from $300 \mathrm{~m}$ to $330 \mathrm{~m}$, while the highest peak lies at about $2500 \mathrm{~m}$ above mean sea level. The area is well drained by a network of streams whose courses are controlled largely by the geologic structures. Most streams have straight channels and flow N-S, NW-SE, or NE-SW. River Song a major river in the area and flows through the central part of the area (Figure 1).

Water is one of the most valuable natural resources that are crucial to the existence of life, and therefore, an adequate supply of safe water for maintaining life and for achieving sustainable development is the impetus for groundwater exploration and evaluation

*Address correspondence to this author at the Department of Geology, Modibbo Adama University of Technology, Yola, Nigeria;

E-mail: anur07@gmail.com
[1]. Groundwater has become immensely important for human water supply in urban and rural areas in developed and developing nations alike [2].

The use of geophysics for both groundwater resource mapping and for water quality, evaluations has increased dramatically over the years. Direct current resistivity method is a common tool for surveying of groundwater in the crystalline rocks and has been successfully employed in groundwater exploration.

The electrical properties of rocks depend on the amount of water, conducting minerals and the resistivity varies with salinity and temperature. Olorunfemi and Fasuyi (1993)[3] adopted the electrical resistivity method to investigate the geo-electrical parameters and hydro-geologic characteristics of parts of basement complex terrain of Nigeria and identified five aquifer units. Other researchers (Olayinka, 1996[4]; Edet and Okereke, 1997[5]; and Nur and Ayuni 2011[6]; and Nur and Matazu, 2011)[7] have utilized resistivity methods as a tool for groundwater exploration in basement terrain where the occurrences of groundwater is due largely to the development of secondary porosity and permeability by weathering and/or fracturing of the parent rocks.

In this study; results of the seventeen (17) vertical electrical soundings (VES) carried out in Song town and environment have assisted in understanding of the groundwater systems of the area. 


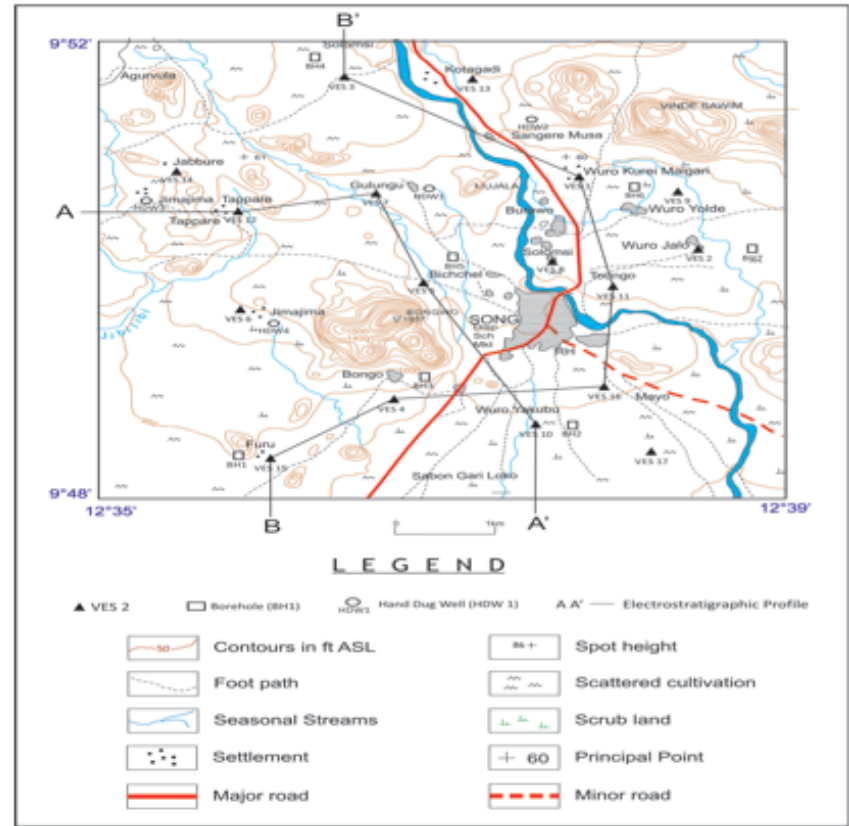

Figure 1: Topographic map of the study area. (Modified from)[14].

\section{GEOLOGY AND HYDROGEOLOGY OF THE AREA}

The area is located within the eastern province of the basement complex of North-eastern Nigeria, and most rocks belong to the older granites of the Pan African Orogeny. The granitic rocks have undergone complete weathering leading to unconsolidated overburden consisting of sands, clays and laterite. Lithologically, the major groups of rocks encountered within the area include gneisses, migmatites, and granites outcropping mainly as a range of hillocks and in some parts overlain by Tertiary alluvium. Gneisses are the dominant rocks and are highly intruded by a series of granite, pegmatite, and some basic intrusions (Figure 2).

The gneissic rocks consist of varieties of predominantly granitic composition and textural variation. The rocks generally outcrop sandwiched between migmatites at the base of slope and granites on top. They exhibit variable color, due largely to the type and proportion of mafic or feldspar mineral content. The mafic minerals are mainly biotite and hornblende. In some sections, especially towards the base of hills, the rocks grade into migmatites gneisses. Petrologically therefore, the gneisses in Song area include; granite gneisses, transition gneisses, porphyroblastic (augen) gneisses, argentite and veined types [8]

Basalt flows are widespread in the study area and are part of the Cameroun Volcanic Line outcropping in Nigeria (Fitton, 1980, 1983)[9, 10]. The rocks are highly weathered leading to unconsolidated weathered overburden consisting of alluvium, sands, laterite, gravels and clays.

Generally, groundwater distribution in crystalline terrain varies from place to place due to the localized nature of the crystalline aquifers. The spatial variation of the aquifer parameters such as porosity, permeability, transmissivity and conductivity can be attributed to, among other causes, tectonic set-up and degree of weathering of near-surface rocks [11].

The occurrence of groundwater is limited to the

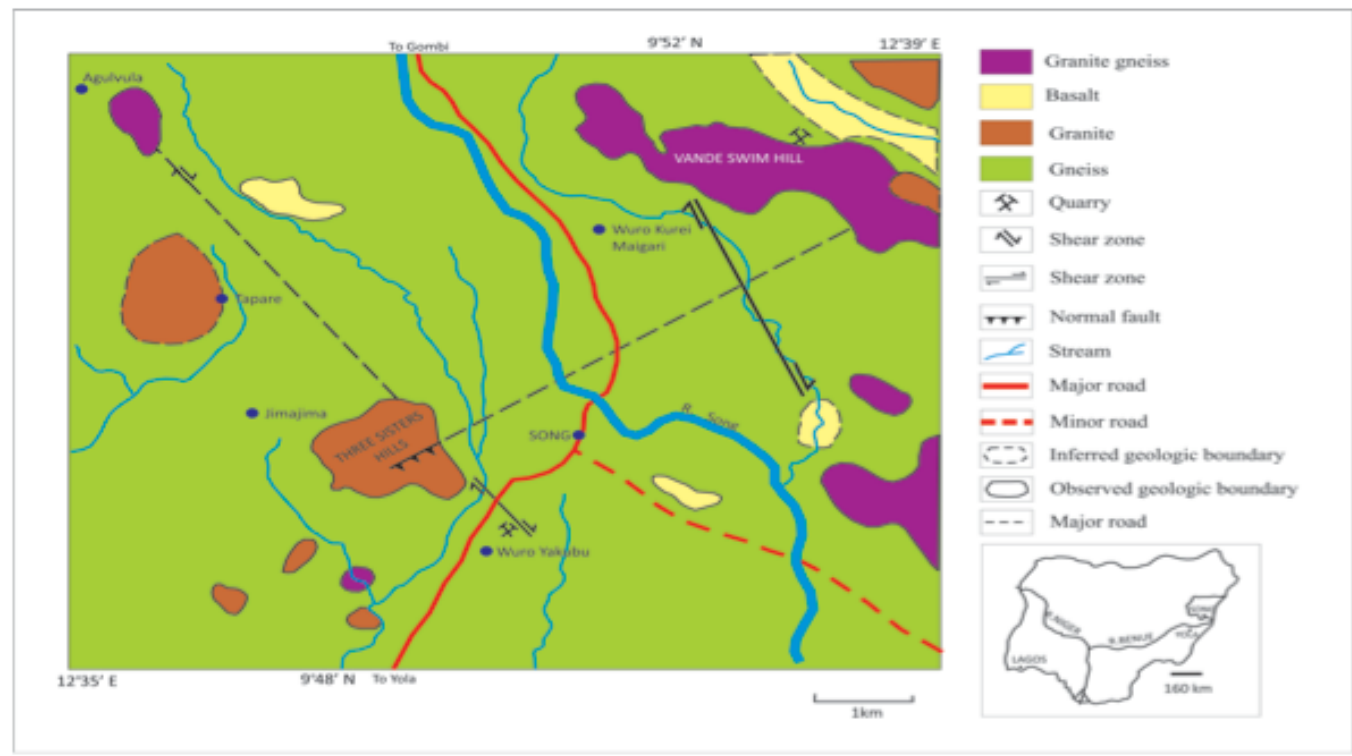

Figure 2: Geologic map of the study area (Modified from)[15]. 
weathered and fractured zones in the basement complex area. However, it is generally a poor source of groundwater [12]. These weathered zones must have appreciable lithologic thickness to be productive source of water. Sources of surface water supply to the study area are mainly the River Song and its major tributaries. The river takes it source from the mountains around the northern part and flow towards the southern part and water supply (Figure 1). It is indeed essential to exploit the available groundwater resources for the communities of Song and its environs.

\section{DATA COLLECTION, ANALYSIS AND RESULTS}

The ABEM Signal Averaging System (SAS 1000) Terrameter was used for collection of seventeen Vertical Electrical soundings (VES) using the Schlumberger configuration with current electrode configuration was carried out in Song and environs of Adamawa State of Nigeria. The apparent resistivities obtained from the fieldwork were plotted on a log-log graph paper. Partial curve matching technique was used in the initial stage of the analysis to obtain the resistivities and thicknesses, which were used as the initial input into a computer program IX1-D software used for computer modelling. The results obtained were used as initial input into computer program, (IX1$D$ ); where it was unsatisfactory the parameters were modified until a smooth layered model with a minimum percentage error is obtained. The computer output of the seventeen VES in the study area is presented in Table 1. This result shows the details of the measured parameters such as thickness of layers, resistivity of layers, transverse resistance, longitudinal conductance and fitting error for all the sounded points.

\section{ISO-RESISTIVITY MAPS}

To understand the subsurface situation, resistivity values corresponding to $A B / 2=30 \mathrm{~m}$ and $A B / 2=80 \mathrm{~m}$ were contoured (Figures $\mathbf{3} \mathbf{a}, \mathbf{b}$ ). In Figure $\mathbf{3 a}$, there are three anomalies, the major anomaly is located at the centre of the study area and has the highest resistivity value of $160 \Omega \mathrm{m}$ and covers an area of $35 \mathrm{~km}^{2}$. The anomaly is elongated towards southeast of the study area. The second anomaly is located in the northeast of the area; the resistivity value is in the ranges between $60 \Omega \mathrm{m}$ to $30 \Omega \mathrm{m}$ and covers a $\Omega \mathrm{m}$ area of 12 $\mathrm{km}^{2}$ (Figure 3a). The third anomaly which is the smallest is located in the south of the second anomaly and resistivity value is between $90 \Omega \mathrm{m}$ to $70 \Omega \mathrm{m}$. the anomaly covers an area of $3.75 \mathrm{Km}^{2}$.

Figure $\mathbf{3 b}$, there are three anomalies, the major anomaly is located at the centre of the study area and has the highest resistivity value of $420 \Omega \mathrm{m}$; while the lowest is $80 \Omega \mathrm{m}$ and covers an area of $36.5 \mathrm{~km}^{2}$. The

Table 1: Summary of Results Obtained from the Computer Output of the 17 Ves in the Study Area

\begin{tabular}{|c|c|c|c|c|c|c|c|c|c|c|c|c|c|c|c|c|c|c|}
\hline \multirow[t]{2}{*}{$S / N$} & \multirow[t]{2}{*}{$\begin{array}{l}\text { VES } \\
\text { Number }\end{array}$} & \multicolumn{3}{|c|}{$\begin{array}{l}\text { Thickness of layers } \\
\text { (meters) }\end{array}$} & \multicolumn{4}{|c|}{ Resistivity of layers $(\Omega \mathrm{m})$} & \multicolumn{3}{|c|}{ Traverse Resistance $\left(\Omega \mathrm{m}^{2}\right)$} & \multicolumn{3}{|c|}{$\begin{array}{l}\text { Longitudinal Conductance } \\
\text { (Siemens) }\end{array}$} & \multicolumn{3}{|c|}{ Elevation (meters) } & \multirow[t]{2}{*}{$\begin{array}{l}\text { Fitting } \\
\text { error } \\
\text { (\%) }\end{array}$} \\
\hline & & $h_{1}$ & $\mathrm{~h}_{2}$ & $h_{3}$ & $\rho_{1}$ & $\rho_{2}$ & $\rho_{3}$ & $\rho_{4}$ & $\mathrm{~T}_{1}$ & $\mathrm{~T}_{2}$ & $\mathrm{~T}_{3}$ & $\mathrm{~S}_{1}$ & $\mathrm{~S}_{2}$ & $\mathrm{~S}_{3}$ & $E_{1}$ & $\mathrm{E}_{2}$ & $E_{3}$ & \\
\hline 1 & VES 1 & 2.79 & 18.30 & - & 13.82 & 17.87 & 5587 & - & 38.55 & 325.23 & - & 0.2018 & 1.0184 & - & -2.79 & -21.04 & - & 0.29 \\
\hline 2 & VES 2 & 0.83 & 5.86 & - & 146.51 & 19.80 & 177.06 & - & 121.6 & 116.02 & - & 0.0056 & 0.2959 & & -0.83 & -6.60 & - & 0.29 \\
\hline 3 & VES 3 & 2.80 & 22.80 & - & 14.98 & 30.16 & 5822 & - & 41.94 & 687.6 & - & 0.1869 & 0.7559 & - & -2.80 & -25.68 & - & 0.25 \\
\hline 4 & VES 4 & 0.23 & 15.95 & - & 3.77 & 23.43 & 3455 & - & 0.867 & 373.7 & - & 0.0610 & 0.6807 & - & -0.23 & -16.18 & - & 0.53 \\
\hline 5 & VES 5 & 2.73 & 46.37 & - & 84.94 & 37.67 & 4165 & - & 231.8 & 1746.75 & - & 0.03214 & 1.2309 & - & -2.73 & -49.10 & - & 0.49 \\
\hline 6 & VES 6 & 3.01 & 10.30 & - & 161 & 24.3 & 163 & & 482.5 & 269.7 & - & 0.0181 & 0.4567 & - & -3.01 & -13.31 & - & 0.73 \\
\hline 7 & VES 7 & 0.62 & 10.58 & - & 270.81 & 58.07 & 9988 & - & 167.9 & 614.38 & - & 0.0022 & 0.1821 & - & -0.62 & 11.20 & - & 0.60 \\
\hline 8 & VES 8 & 3.93 & 3.17 & - & 59.94 & 9.75 & 6683 & - & 235.5 & 30.91 & - & 0.0655 & 0.3251 & - & -3.93 & -7.10 & - & 0.88 \\
\hline 9 & VES 9 & 1.48 & 17.31 & - & 111.71 & 12.54 & 6077 & - & 15.48 & 14.16 & - & 0.0582 & 1.4935 & - & -1.48 & -18.79 & - & 0.76 \\
\hline 10 & VES 10 & 1.00 & 6.36 & - & 129.87 & 6.77 & 4345 & - & 129.7 & 43.12 & - & 0.0077 & 0.9380 & - & -1.00 & -7.36 & - & 0.49 \\
\hline 11 & VES 11 & 4.70 & 1.78 & - & 13.99 & 24.02 & 9230 & - & 65.75 & 523.15 & - & 0.3359 & 0.9067 & - & -4.70 & -6.48 & & 0.59 \\
\hline 12 & VES 12 & 1.95 & 20.89 & - & 92.54 & 28.12 & 5513 & - & 180.5 & 587.43 & - & 0.0210 & 0.7428 & - & -1.95 & -22.84 & - & 0.24 \\
\hline 13 & VES 13 & 0.63 & 3.59 & - & 126.38 & 6.98 & 9236 & - & 79.61 & 25.05 & - & 0.0049 & 0.5143 & & -0.63 & -4.22 & - & 0.53 \\
\hline 14 & VES 14 & 3.39 & 4.81 & - & 4.43 & 7.08 & 9353 & - & 15.02 & 34.05 & - & 0.7652 & 0.6793 & - & -3.39 & -8.20 & - & 0.10 \\
\hline 15 & VES 15 & 2.85 & 1.91 & - & 6.73 & 50.63 & 82.27 & - & 19.18 & 96.70 & - & 0.4234 & 0.0377 & - & -2.85 & -4.76 & - & 0.58 \\
\hline 16 & VES 16 & 0.49 & 14.10 & - & 9.14 & 57.54 & 7671 & - & 4.47 & 811.3 & - & 0.0536 & 0.2450 & - & -0.49 & -14.59 & - & 0.28 \\
\hline \multirow[t]{2}{*}{17} & VES 17 & 0.58 & 1.60 & 9.48 & 26.91 & 435.3 & 11.51 & 2886 & 15.61 & 696.64 & 109.11 & 0.0215 & 0.0036 & 0.8236 & -0.58 & -2.18 & -11.66 & 0.40 \\
\hline & Mean & 2.00 & 12.09 & 9.48 & 75.14 & 50.00 & 5150.52 & 2886 & 108.5 & 411.52 & 109.11 & 0.1332 & 0.6180 & 0.8236 & -2.00 & -12.77 & -11.66 & 0.47 \\
\hline
\end{tabular}

VES: Vertical Electrical Sounding 


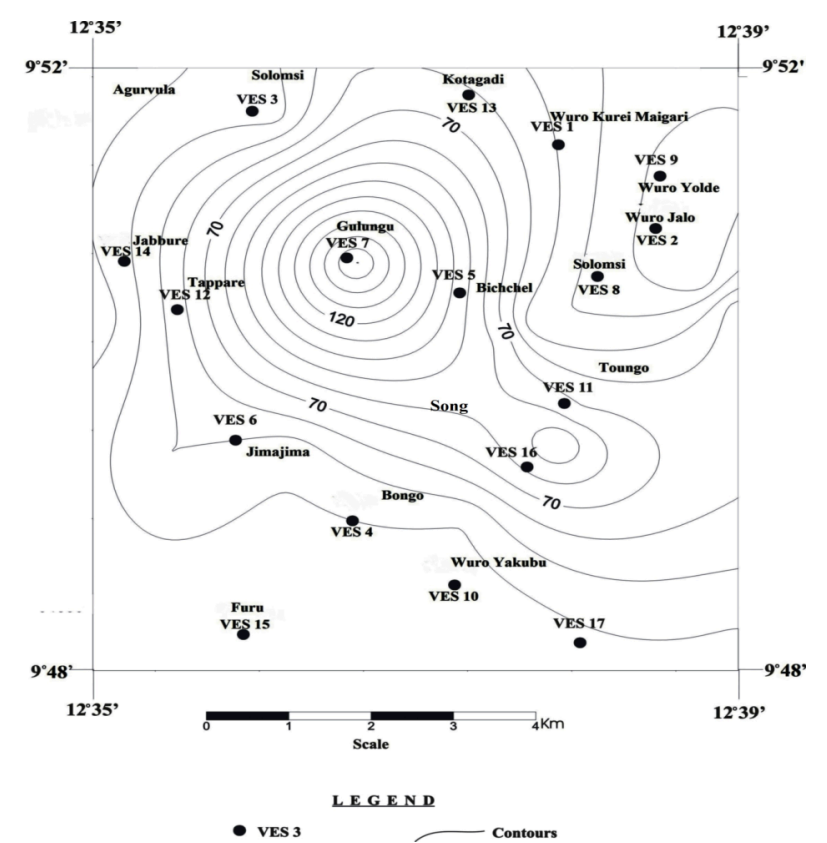

Figure 3a: Iso-resistivity map of $A B / 2=30 \mathrm{~m}$. (Contour Interval $=10 \Omega \mathrm{m})$.

anomaly is elongated towards southeast of the study area. The second anomaly is located in the northeast of the area; the resistivity value is in the ranges between $240 \Omega \mathrm{m}$ to $60 \Omega \mathrm{m}$ and covers an area of $27.15 \mathrm{~km}^{2}$ (Figure $3 \mathbf{b}$ ). The third anomaly which is the smallest is located in the south of the second anomaly and resistivity value is between $120 \Omega \mathrm{m}$ to $60 \Omega \mathrm{m}$; the area covered the third anomaly is $6.859 \mathrm{Km}^{2}$.

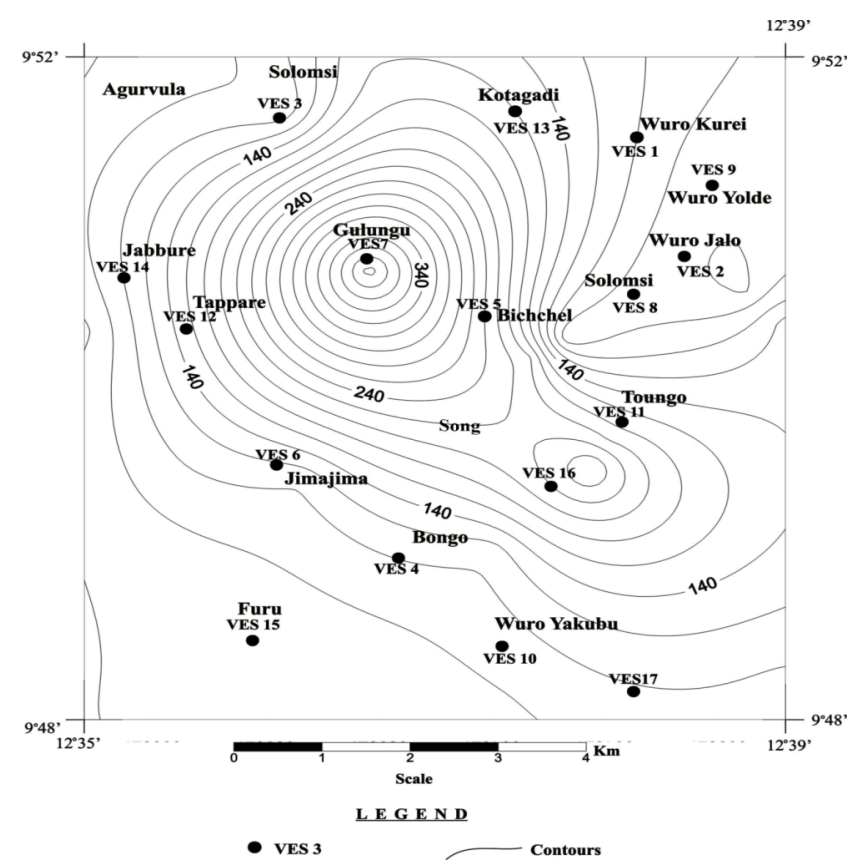

Figure 3b: Iso-resistivity map of $A B / 2=80 \mathrm{~m}$. (Contour interval $=20 \Omega \mathrm{m})$.

\section{GEOELECTRO-STRATIGRAPHIC SECTIONS}

Geo-electrostratigraphic sections A-A' shown in Figure 4 has three layers and is $6.9 \mathrm{~km}$ long. The first layer is the top soil; the layer has its lowest resistivity value of $85 \Omega \mathrm{m}$ and highest with a resistivity value of $270 \Omega \mathrm{m}$. The thickness of the layer varies between $0.62 \mathrm{~m}$ and $2.73 \mathrm{~m}$. The second layer is highly weathered basement; the resistivity varies between $6.77 \Omega \mathrm{m}$ and $58 \Omega$; while the thickness of the second layer is from $6.36 \mathrm{~m}$ and $46.37 \mathrm{~m}$. The resistivity of third layer is between $4165 \Omega \mathrm{m}$ and $9988 \Omega \mathrm{m}$ and represents fresh basement rocks.

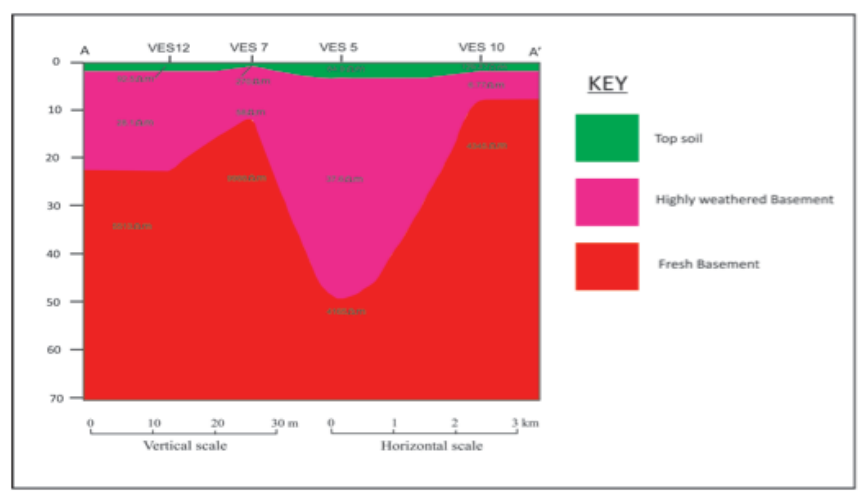

Figure 4: Geo-electro stratigraphic section of profile A-A'.

Geo-electrostratigraphic sections B-B' shown in Figure $\mathbf{5}$ has three layers; the first layer is the top soil and the resistivity of the layer is in between $3.77 \Omega \mathrm{m}$ and $14.9 \Omega \mathrm{m}$; while the thickness of the layer is $0.23 \mathrm{~m}$ and $4.7 \mathrm{~m}$. The second layer is highly weathered basement; the resistivity varies between $23.4 \Omega \mathrm{m}$ and $57 \Omega$; while the thickness of the second layer is from $1.78 \mathrm{~m}$ and $22.8 \mathrm{~m}$. The resistivity of third layer is between $82 \Omega \mathrm{m}$ and $5822 \Omega \mathrm{m}$ and represents fresh basement rocks.

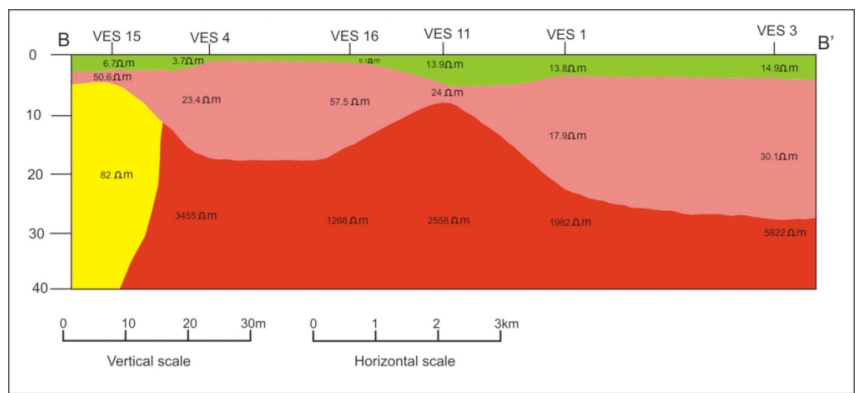

Figure 5: Geo-electrostratigraphic section of profile B-B'.

The conditions for accumulation of groundwater include thick layer of unconsolidated and highly weathered/fractured basement rock. From the qualitative and quantitative interpretations of the 
analyzed data the second layer is the potential aquiferous zones in the study area and should be target areas for drilling purposes. Areas with minute thickness of the second layer were identified.

The potential viable areas for groundwater development in the area include; Woro Kurei, Maigari, WuroJalo, Sangaya, Bongo, Bichchel, Jima Jima, WuroYolde, Tappare, Sabon-gariLoko and Furu respectively because of the considerable thickness of the weathered/fractured basement.

\section{WATER QUALITY ANALYSIS}

Eleven water samples were collected from seven boreholes and four hand dug wells in a one liter capacity properly washed plastic bottles. Boreholes were pumped for few minutes to allow steady flow before samples were collected. The results of the analysis of water samples collected from seven Boreholes and four Hand Dug Wells presented in Table 2 was used in the evaluation of groundwater water quality for drinking and domestic use in Song and environs. The total dissolve solid in the area vary from $68 \mathrm{mg} / \mathrm{l}$ to $137.83 \mathrm{mg} / \mathrm{l}$; this result is permissible compared with the [13] standard of up to $500 \mathrm{mg} / \mathrm{l}$ as the permissible value for drinking. $\mathrm{Mg}^{2+}$ concentrations vary from $30.01 \mathrm{mg} / \mathrm{l}$ to $71 \mathrm{mg} / \mathrm{l}$ this value is within the permissible range of $200 \mathrm{mg} / \mathrm{l}$ while concentration of $\mathrm{CO}_{3}{ }^{-}$vary from $0.0 \mathrm{mg} / \mathrm{l}$ to $3.40 \mathrm{mg} / \mathrm{l}$, it has a mean value of $1.43 \mathrm{mg} / \mathrm{l}$, all these values falls within the permissible range for drinking water. $\mathrm{HCO}_{3}{ }^{-}$concentration varies from $20 \mathrm{mg} / \mathrm{l}$ to $466 \mathrm{mg} / \mathrm{l}$ with a mean value of $374.18 \mathrm{mg} / \mathrm{l}$. The $\mathrm{SO}_{4}{ }^{2-}$ concentration range from $16.11 \mathrm{mg} / \mathrm{l}$ to $36.17 \mathrm{mg} / \mathrm{l}$ with a mean value of $23.91 \mathrm{mg} / \mathrm{l}$, this low concentration of sulfate is permissible for drinking water.

The $\mathrm{SO}_{4}{ }^{2-}$ concentration in the analyzed sample is probably derived from oxidation of sulfate in the igneous rocks. $\mathrm{Cl}^{-}$concentration in the area also shows concentration values which vary from $27.01 \mathrm{mg} / \mathrm{l}$ to $80.01 \mathrm{mg} / \mathrm{l}$, these values are permissible for drinking compared with the standard of $250 \mathrm{mg} / \mathrm{l}$. High concentrations of chloride give a salty taste to water and beverages. Taste thresholds for the chloride anion depend on the associated cations and are in the range of $200-300 \mathrm{mg} / \mathrm{l}$ for sodium, potassium and calcium chloride. The probable source of chloride in the study area could be attributed to anthropogenic activities. $\mathrm{Fe}^{2+}$ concentration in the study area ranges from $0.006 \mathrm{mg} / \mathrm{l}$ to $0.227 \mathrm{mg} / \mathrm{l}$ this value is within the permissible range of $0.3 \mathrm{mg} / \mathrm{l} . \mathrm{Na}^{+}$concentration in the study area shows a very low concentration values which vary from $0.12 \mathrm{mg} / \mathrm{l}$ to $4.83 \mathrm{mg} / \mathrm{l}$. $\mathrm{K}^{+}$concentration in the study area ranges from $5.81 \mathrm{mg} / \mathrm{l}$ to $9.30 \mathrm{mg} / \mathrm{l}$ with a mean value of $7.29 \mathrm{mg} / \mathrm{l}$ (Table 2).

The hydro-geochemical results in the area shows that BH4, HDW1, HDW2, HDW3 and HDW4 have anomalous $\mathrm{NO}_{3}^{-}$concentration levels of $56.10 \mathrm{mg} / \mathrm{l}$, $50.93 \mathrm{mg} / \mathrm{l}, \quad 67.17 \mathrm{mg} / \mathrm{l}, \quad 62.0 \mathrm{mg} / \mathrm{l}$ and $58.9 \mathrm{mg} / \mathrm{l}$ respectively the concentration of $\mathrm{NO}_{3}^{-}$in these wells are in excess when compared with the standard of $50 \mathrm{mg} / \mathrm{l}$ for drinking water (Table 2); this may be attributed to anthropogenic activities such as application of chemical fertilizer to boast plant growth and indiscriminate waste disposal practices.

The statistics of the physical, chemical and biological parameters for the seven boreholes indicates moderately acidic condition with a mean $\mathrm{pH}$ value of 6.09. Electrical Conductivity, Total Dissolved Solids, Turbidity, Total hardness and Total Coliform count reveal mean values of $139.9 \mu \mathrm{s} / \mathrm{cm}, 89.92,0.354 \mathrm{NTU}$, $95.21,4 \mathrm{cfu} / \mathrm{ml}$ respectively. All the analyzed cations and anions reveal ranges and mean values within the set limit [13].

Results from Hand-Dug Wells indicate an acidic condition with a mean $\mathrm{pH}$ value of 5.58.Electrical Conductivity, Total Dissolved Solids, Turbidity, Total hardness and Total Coliform count reveal mean values of $191 \mu \mathrm{s} / \mathrm{cm} ; 124.99 ; 0.695 \mathrm{NTU} ; 106.56 ; 19 \mathrm{cfu} / \mathrm{ml}$ respectively. The analyzed cations reveal ranges and mean values within the set limit (Table 2). Apart from anomalous nitrate concentration in all the Hand-Dug Wells all the anions are within the set limit for human and domestic uses. Based on the mean values of the chemical parameters, the cations were in order of abundance as $\mathrm{Ca}^{2+}>\mathrm{Mg}^{2+}>\mathrm{K}^{+}>\mathrm{Na}^{+}>\mathrm{Fe}^{2+}>\mathrm{Mn}^{2+}>\mathrm{Cu}^{2+}$ while the anions reveal order of abundance as $\mathrm{HCO}_{3}{ }^{-}>$ $\mathrm{Cl}^{-}>\mathrm{NO}_{3}{ }^{-}>\mathrm{SO}_{4}{ }^{2-}>\mathrm{CO}_{3}{ }^{-}>\mathrm{F}^{-}$. TDS indicates concentration occurring very low which suggest that the groundwater in the area is characterized by low degree of mineralization.

The result of the quality water analysis indicates two major sources of chemical constituents interpreted as the effects of rock-water interaction, leading to silicate weathering and the effects of anthropogenic activities, such as application of chemical fertilizers, and indiscriminate dumping of house hold solid wastes in the area as well as human and animal faeces. 
Table 2: Result of Physio-Chemical (mg/l) and Microbiological (cfu/ml) Analysis of Water Sample from Seven BH and Four HDW in Song and Environs

\begin{tabular}{|c|c|c|c|c|c|c|c|c|c|c|c|c|c|c|c|c|c|c|c|c|}
\hline$S / N$ & $\begin{array}{l}\mathrm{BH} / \\
\text { HDW }\end{array}$ & $\mathrm{pH}$ & $\begin{array}{c}\text { EC } \\
(\mu \mathrm{s} / \mathrm{cm})\end{array}$ & $\begin{array}{l}\text { Turb- } \\
\text { idity } \\
\text { (NTU) }\end{array}$ & TDS & $\begin{array}{c}\text { Total } \\
\text { Hardn } \\
\text { ess }\end{array}$ & $\mathrm{K}^{+}$ & $\mathrm{Ca}^{2+}$ & $\mathrm{Cu}^{2+}$ & $\mathrm{Na}^{+}$ & $\mathrm{Mg}^{2+}$ & $\mathrm{Fe}^{2+}$ & $\mathrm{Mn}^{2+}$ & $\mathrm{CO}_{3}{ }^{2 \cdot}$ & $\mathrm{HCO}_{3}{ }^{-2}$ & $\mathbf{F}$ & $\mathrm{NO}_{3}{ }^{2 \cdot}$ & $\mathrm{Cl}^{\circ}$ & $\mathrm{SO}_{4}{ }^{2-}$ & $\begin{array}{l}\text { Total } \\
\text { Colif- } \\
\text { orm } \\
\text { count }\end{array}$ \\
\hline 1 & BH1 & 4.88 & 149.8 & 0.075 & 95.67 & 89.010 & 5.81 & 43.41 & 0.000 & 2.73 & 39.88 & 0.183 & 0.007 & 0.00 & 466 & 0.078 & $\begin{array}{c}36.2 \\
7\end{array}$ & 42.03 & 17.92 & 2.00 \\
\hline 2 & BH2 & 6.0 & 148.1 & 0.015 & 92.18 & 131.72 & 6.93 & 66.83 & 0.000 & 3.00 & 68.13 & 0.006 & 0.00 & 1.00 & 376 & 0.108 & $\begin{array}{c}39.0 \\
0\end{array}$ & 37.26 & 27.62 & 7.00 \\
\hline 3 & BH3 & 5.88 & 152.0 & 0.150 & 97.19 & 111.71 & 5.97 & 58.99 & 0.000 & 2.17 & 49.68 & 0.062 & 0.009 & 1.40 & 366 & 0.170 & $\begin{array}{c}27.6 \\
2\end{array}$ & 43.66 & 19.66 & 2.00 \\
\hline 4 & $\mathrm{BH} 4$ & 5.53 & 166.0 & 0.009 & 103.11 & 142.11 & 7.17 & 75.21 & 0.012 & 2.11 & 71.00 & 0.017 & 0.001 & 0.00 & 423 & 0.012 & $\begin{array}{c}56.1 \\
0\end{array}$ & 30.11 & 28.11 & 5.00 \\
\hline 5 & BH5 & 6.32 & 137.3 & 0.117 & 89.66 & 120.92 & 6.17 & 60.03 & 0.000 & 2.10 & 63.17 & 0.071 & 0.002 & 3.40 & 417 & 0.093 & $\begin{array}{c}22.9 \\
3\end{array}$ & 47.77 & 21.83 & 4.00 \\
\hline 6 & BH6 & 6.93 & 103 & 0.905 & 68 & 54.62 & 6.10 & 27.06 & 0.002 & 0.12 & 30.01 & 0.016 & 0.004 & 0.00 & 201 & 0.83 & $\begin{array}{c}16.0 \\
7\end{array}$ & 27.01 & 24.04 & 0.00 \\
\hline 7 & BH7 & 5.91 & 133.0 & 0.930 & 89.38 & 10.220 & 6.00 & 59.00 & 0.014 & 2.20 & 50.06 & 0.121 & 0.023 & 0.00 & 348 & 0.120 & $\begin{array}{c}32.1 \\
6\end{array}$ & 47.00 & 16.11 & 6.00 \\
\hline 8 & HDW1 & 5.27 & 190.0 & 1.007 & 121.79 & 101.62 & 8.77 & 52.17 & 0.003 & 4.83 & 55.21 & 0.227 & 0.011 & 2.70 & 316 & 0.103 & $\begin{array}{c}50.9 \\
3\end{array}$ & 61.62 & 18.24 & 12.0 \\
\hline 9 & HDW2 & 4.98 & 198.8 & 0.910 & 127.38 & 127.81 & 9.11 & 59.87 & 0.000 & 4.16 & 61.01 & 0.152 & 0.014 & 3.10 & 400 & 0.570 & $\begin{array}{c}67.1 \\
7\end{array}$ & 80.01 & 23.01 & 21.0 \\
\hline 10 & HDW3 & 6.17 & 201.7 & 0.205 & 137.83 & 87.670 & 9.30 & 43.92 & 0.010 & 4.22 & 39.82 & 0.103 & 0.024 & 2.20 & 411 & 1.003 & $\begin{array}{c}62.0 \\
0\end{array}$ & 59.81 & 36.17 & 16.0 \\
\hline \multirow[t]{3}{*}{11} & HDW4 & 5.93 & 173.6 & 0.660 & 112.98 & 109.17 & 8.93 & 61.03 & 0.001 & 3.90 & 57.82 & 0.137 & 0.021 & 2.00 & 392 & 0.42 & $\begin{array}{c}58.9 \\
0\end{array}$ & 71.21 & 30.37 & 27.0 \\
\hline & Mean & 5.8 & 159.39 & 0.453 & 103.19 & 98.78 & 7.29 & 55.22 & 0.004 & 2.86 & 53.25 & 0.099 & 0.010 & 1.43 & 374.18 & 0.318 & $\begin{array}{c}42.6 \\
5\end{array}$ & 49.77 & 23.91 & 10.2 \\
\hline & $\begin{array}{l}\text { WHO } \\
2011\end{array}$ & $\begin{array}{l}6.5- \\
8.5\end{array}$ & $0-1000$ & $0-5$ & 0- 500 & $0-150$ & $\begin{array}{c}0- \\
200\end{array}$ & $0-200$ & $0-2$ & $0-50$ & $0-200$ & $0-0.3$ & $0-0.4$ & $0-120$ & $1-1000$ & $\begin{array}{l}0- \\
1.5\end{array}$ & $0-50$ & $1-250$ & $0-100$ & $1-10$ \\
\hline
\end{tabular}

BH: Borehole; HDW: Hand-Dug Well; EC: Electrical Conductivity; TDS: Total Dissolved Solid.

\section{CONCLUSIONS}

The information gathered from qualitative and quantitative interpretation of the seventeen Vertical Electrical Soundings in the study area revealed that most of the curves in the study area are the H-type curve constituting of $52.94 \%$ and the A-type curve which constitutes $41.17 \%$ describing three earth models with only one curve depicting a four layered earth model. The qualitative and quantitative interpretation of the seventeen vertical electrical sounding (VES) has helped in delineating the depth to the basement in the study area. The average thickness of the first layer is 2 meters with a mean resistivity of $75.14 \Omega \mathrm{m}$; and represents the top soil and clay. The second layer has an average thickness of $12.09 \mathrm{~m}$ with a mean resistivity of $50.0 \Omega \mathrm{m}$. The layer is unconsolidated and highly weathered/fractured basement. The average resistivity value of the third layer is $5150 \Omega \mathrm{m}$ and represents the fresh basement.

The groundwater potentials of the area from analysis and interpretation of the resistivity data is therefore the second layer which is the unconsolidated and highly weathered/fractured basement rock. Results of analyses of seven boreholes and four hand dug wells revealed that the groundwater in Song and environs is moderately acidic with a mean $\mathrm{pH}$ value of $5.8 \mathrm{mg} / \mathrm{l}$. The overall total hardness average of $98.72 \mathrm{mg} / \mathrm{l}$ was observed and thus, the water can be classified as moderately soft. The level of total dissolve solid in the groundwater is low with a mean value of $103.19 \mathrm{mg} / \mathrm{l}$ indicating low mineralization in the area. All the Hand-Dug wells in the study area have high concentration of nitrate and total coliform count of $50.93 \mathrm{mg} / \mathrm{l}$ to $67.17 \mathrm{mg} / \mathrm{l}$ and $12 \mathrm{cfu} / \mathrm{ml}$ to $27 \mathrm{cfu} / \mathrm{ml}$ respectively. This high value may be attributed to anthropogenic activities such as chemical fertilizer application and indiscriminate dumping of house hold solid wastes in the area as well as animals and human faeces. The high concentration of total coliform count was also observed in $\mathrm{BH} 4$ because of the shallow depth. The groundwater in the study area is generally good for human as well as industrial and agricultural uses.

\section{REFERENCES}

[1] Topfer K. Editorial comments on freshwater. Our Planet 1998; 9(4): 3.

[2] Omosuyi GO. Geoelectric assessment of groundwater prospect and vulnerability of overburden aquifers at Idanre, South Western Nigeria; Ozean Journal of Applied Sciences 2010; 3(1): 19-28. 
[3] Olorunfemi MO and Fasuyi, SA. Aquifer types and the geoelectric/hydrogeologic characteristics of part of the Central basement terrain of Nigeria (Niger State). J Afr Earth Sci 1993; 16: 317-403.

http://dx.doi.org/10.1016/0899-5362(93)90051-Q

[4] Olayinka AI. Non uniqueness in the interpretation of bedrock resistivity from sounding curves and hydrological implications. J Nig Assoc Hydro Geol 1996; 7(1 and 2): 4955.

[5] Edet $\mathrm{AE}$ and Okereke CS. Assessment of hydrogeologic conditions in basement aquifers of the Precambrian Oban massif, southeastern Nigeria. Journal of applied Geophysics 1997; 36: 195-204.

http://dx.doi.org/10.1016/S0926-9851(96)00049-3

[6] Nur A and Ayuni KN. Hydro-geophysical study of Michika and environs, northeast Nigeria. International Journal of the Physical Sciences 2011; 6(34): 7816-7827.

[7] Nur A and Matazu HI. Hydrogeo-electrical Investigation of Fufore and its Environs of Adamawa State, North-eastern Nigeria. International Journal of Earth Sciences and Engineering (IJEE), Hyderabad, India 2011; 04 (5): 796-806.

[8] Adekeye JD and Ntekim EE. The geology of Song area in southern Hawal massif, N.E Nigeria. Zuma jour Pure and Applied Sci 2004; 6(2): 145-157.
[9] Fitton JG. Benue Trough and Cameroun line. A migrating Rift system in West Africa; Earth and planetary Sci. Letters 1980; 51: 473-138. http://dx.doi.org/10.1016/0012-821X(80)90261-7

[10] Fitton JG. Active versus passive continental rifting; evidence from West Africa rift system. Tectonophysics 1983; 94: 473481.

http://dx.doi.org/10.1016/0040-1951(83)90030-6

[11] Barker R, Rao TV and Thangarajan M. Delineation of contaminant zone through electrical imaging technique. Curr Sci 2001; 81(3): 277-283.

[12] Todd DK. Groundwater hydrogeology. $2^{\text {nd }}$ edition John Wiley and sons. New York 1980: 535.

[13] WHO. Guidelines for Drinking Water Quality, $4^{\text {th }}$ ed. World Health Organization, Geneva 2011.

[14] Federal Survey Nigeria. Topographical map of Zummo (Sheets 176, NW) Nigeria, 1968.

[15] Bassey NE. Structural geological mapping and interpretation of landsat and aeromagnetic data over parts of hawal basement complex, northeast nigeria. Doctoral Thesis Abubakar Tafawa Balewa University Bauchi 2006.

Received on 27-05-2015

Accepted on 05-07-2015

Published on 30-06-2015

DOI: http://dx.doi.org/10.15377/2409-5710.2015.02.01.3

(c) 2015 Yakubu and Nur; Avanti Publishers.

This is an open access article licensed under the terms of the Creative Commons Attribution Non-Commercial License (http://creativecommons.org/licenses/by-nc/3.0/) which permits unrestricted, non-commercial use, distribution and reproduction in any medium, provided the work is properly cited. 